\title{
Dynamics and Determinants of Inflation During the COVID-19 Pandemic Period in European Countries: A Spatial Panel Data Analysis
}

\author{
COVID-19 Pandemi Döneminde Enflasyonun Belirleyicileri: Avrupa Ülkeleri Üzerine Bir \\ Mekansal Panel Veri Analizi
}

\author{
Seyfettin ERDOĞAN ${ }^{1}$ \\ (D) 0000-0003-2790-4221 \\ Durmuş Çağrı YILDIRIM ${ }^{2}$ \\ (D) 0000-0003-4168-2792 \\ Ayfer GEDÍKL $\dot{I}^{1}$ \\ (D) 0000-0002-7128-1976
}

\begin{abstract}
Aim: The recent macroeconomic problems in the global economy are highly related to the coronavirus disease 2019 (COVID-19) pandemic. Since the highest spread of the disease is observed in the European countries, it is worthwhile to investigate the macroeconomic indicators in the European Union (EU) member and the candidate countries. Inflation is one of the most important indicators to examine since it may directly affect many macroeconomic variables. In this study, the determinants of inflation in the $28 \mathrm{EU}$ members and candidate states are investigated.

Material and Methods: In this study, the determinants of inflation in the $28 \mathrm{EU}$ members and candidate states are investigated for January 2020-July 2020 using spatial panel data analysis. Results: The empirical results indicated that the exchange rate and money supply ratios were reasons of the increase in inflation. There is also increasing pressure on the inflation rates due to the domestic money supply and exchange rate variables as well as the neighborhood relations between countries (positive spatial effects).

Conclusion: It is an important finding that macroeconomic problems in each sample country are also affected by developments in neighboring countries as well as internal dynamics. Continuous development of economic, social, and political cooperation between neighboring countries at the regional level is essential. It is reasonable for every country to develop selfsufficient strategies in the fields of agriculture, food, technology, and pharmaceutical industries in case of global disasters. Regional cooperation should not be limited to the development of sectors that stand out during the pandemic period.

Keywords: COVID-19; inflation; EU countries; spatial panel data analysis.
\end{abstract}

\section{ÖZ}

Amaç: Küresel ekonomide son dönemde yaşanmakta olan makroekonomik sorunlar, koronavirüs hastalığı 2019 (coronavirus disease 2019, COVID-19) pandemisi ile yakından ilgilidir. Hastalığın en yüksek yayılımı ağırlıklı olarak Avrupa ülkelerinde görüldüğünden, Avrupa Birliği (AB) üyesi ve birliğe aday ülkelerdeki makroekonomik göstergeleri araştırmak anlamlı olacaktır. Enflasyon, birçok makroekonomik değişkeni doğrudan etkileyebileceği için incelenmesi gereken en önemli göstergelerden biridir. Bu çalışmada 28 AB üyesi ve birliğe aday ülkede enflasyonun belirleyicileri araştırılmıştır.

Gereç ve Yöntemler: Bu çalışmada, Ocak 2020-Temmuz 2020 dönemi ele alınarak 28 AB üyesi ve birliğe aday ülkede enflasyonun belirleyicileri mekansal panel veri analizi kullanılarak araştırılmıştır.

Bulgular: Ampirik sonuçlar, döviz kuru ve para arzındaki değişimlerin enflasyondaki artışın en belirgin nedenleri olduğunu göstermiştir. Yurt içi para arzı ve döviz kuru değişkenlerinin yanı sıra ülkeler arası komşuluk ilişkileri nedeniyle de enflasyon oranları üzerinde artan bir baskı olduğu gözlenmiştir (pozitif mekansal etkiler).

Sonuç: Her örnek ülkenin yereldeki makroekonomik sorunlarının, iç dinamikler yanında komşu ülkelerdeki gelişmelerden de etkilendiği önemli bir bulgudur. Pandemi sürecinde, bölgesel düzeyde komşu ülkeler arasında ekonomik, sosyal ve politik işbirliğinin geliştirilmesi elzemdir. Pandemi döneminde, her ülkenin tarım, gıda, teknoloji ve ilaç endüstrileri alanlarında kendi kendine yeten stratejiler geliştirmesi akılcı bir strateji olacaktır. Bölgesel işbirliği, pandemi döneminde öne çıkan sektörlerin gelişimi ile sınırlı kalmamalı, geniş katılımlı işbirlikleri her alanda ele alınmalıdır.

Received / Geliş Tarihi : 12.09 .2 Accepted / Kabul Tarihi : 11.11.2020 Available Online /

Anahtar kelimeler: COVID-19; enflasyon; AB ülkeleri; mekansal panel veri analizi. 


\section{INTRODUCTION}

The coronavirus disease 2019 (COVID-19) pandemic caused unprecedented shocks in all sectors. Besides, the pandemic caused different and massive uncertainties both in developed and developing countries such as stock market volatility, economic policy uncertainty, uncertainty about employment, and future of GDP growth. The uncertainty became even worse during and after the shutdown (1). In his speech on the great uncertainty about the COVID-19 pandemic, Fed Chairman Jerome Powell (2) expressed that "In the best of times, predicting the path of the economy with any certainty is difficult. We are now experiencing a whole new level of uncertainty, as questions only the virus can answer complicate the outlook".

Related to the uncertainty, the impact of pandemic has not been the same in all sectors. While there is a great collapse in consumption during the lockdown, there are upward pressures on the reduction of real output (3). What is more, while contraction trends are emerging in sectors such as transportation and tourism, significant positive improvements are observed in the sectors that make a positive contribution to the process of combating the pandemic. For policymakers, not only the sectoral developments but also the improvements in the whole economy are important. When the positive and negative developments on the sectoral basis are evaluated collectively, it is possible to conclude that a recession has occurred in all economies during the pandemic process. Exacerbating recession and decreasing growth rates cause economic problems such as increases in unemployment and decreases in public income.

The contraction of total demand during the pandemic period and the sharp falls in prices of inputs used in production are positive factors to control inflation. Nevertheless, it should be emphasized that the supply of intermediate and capital goods has become very difficult. The disruption of the supply chain causes a decline in production. Under normal conditions, the contraction in demand causes the prices to decrease. However, if the supply shrinks as demand shrinks, price increases may occur. In this case, it is difficult to control inflationary trends due to the imbalance between supply and demand. During the pandemic period, the deterioration of the supply chain, as well as the developments affecting inflation rates, can be discussed under the following headings.

\section{Increase and Uncertainty in Exchange Rates}

During the pandemic period, there is an increasing trend in exchange rates, especially in developing countries. Foreign capital outflow is the main reason for the increase in exchange rates. Besides, investors convert their cash in national currency into more reliable foreign currencies. The increase in foreign currency demand causes the national currency to depreciate. The unpredictability of when the pandemic will end increases the uncertainty in the exchange rate increase. The increase and uncertainty in exchange rates trigger production cost increases and ultimately price increases.

\section{Monetary Expansion}

During the pandemic period, one of the strategies for demand increase is monetary expansion. Most developed and developing economies resorted to monetary expansion in order to alleviate the contraction tendencies in their economies. Monetary expansion, which is not consistent with the increase in production, will increase inflationary pressure.

Massive shocks such as the pandemic to the global economy will probably bring turning points. Nowadays, it is a fact that the risks are difficult to assess and the stability of the global exchange rate system is getting more problematic. Ilzetzki et al. (4) expressed that systemic economic crises generally produce major turning points. The authors pointed out that the global exchange rate system has increasing stability at its core. However, due to the pandemic, the risks are hard to evaluate. The authors also indicated that the recent trend reflects the paralysis of monetary policy at the zero bound and today's stability might mask fragilities, but not strengths.

Actually, IMF (5) expressed that COVID-19 pandemic is the worst economic downturn since the Great Depression. The pandemic negatively impacted the local economies and the risk is rising in the countries more affected by the pandemic such as the EU countries. Inflation is one of the most important indicators that worths examining since it may directly affect many macroeconomic variables such as consumer expenditures, exchange rates, cost of production, and interest rates.

Inflation is not the only variable that needs to be carefully monitored during the pandemic period. Aside from inflation, the data obtained by investigating the impacts of the pandemic on economic growth, foreign trade, borrowing, and financial markets should be used in policymaking processes.

In most of the studies on the pandemic period, the effects of the policy implementations applied to reduce the negative effects of the Pandemic on the economy as well as the direct effect of the Pandemic on the economic indicators are discussed. Besides, all macroeconomic variables can be included in the analyzes of the studies on the pandemic period together. However, making each macroeconomic variable a subject of research separately will contribute to obtaining more specific results. During the pandemic period, it was observed that economic growth rates declined due to the recession. This process conveyed increasing unemployment rates. Many countries initiated expansionary monetary policies to alleviate the negative effects of recession. Therefore, it is important to predict the tendency of the inflation rate in the period of increasing unemployment for determining the policies to combat the recession.

At this point, two important questions arise: Does inflation increase while expansionary policies are implemented? Which variables affect the inflation rate in this period?

The aim of this study is to investigate the main determinants of inflation in the first 7 months of 2020 when the COVID-19 crisis was intense for 28 European Union (EU) members and candidate EU members. Spatial Panel Data Analysis was preferred in the study. There are two main reasons for including the European countries in the scope of the research. The first reason is that European countries take the first place regarding the number of cases and deaths due to the COVID-19 pandemic. The second reason is that we have a theoretical expectation that the spatial impact is high among the EU countries. Changes in 
macroeconomic indicators are affected both by neighboring countries and local improvements. Also, the real-time effects of the pandemic on employment and spending are well documented, much less is known about how the pandemic is impacting inflation. As far as we know, there is no other study investigating the determinants of inflation during the COVID-19 pandemic period using the spatial data analysis method. This study will contribute to the literature by exploring the determinants of inflation during the Pandemic period using the spatial data analysis method.

The rest of the work consists of three parts. The first part includes the literature review, in the next part we explained the data set and methodology, and in the third part, we provided the empirical analysis and findings.

\section{Literature Review}

It is a fact that there is a change in consumption trends as well as increasing uncertainties due to COVID-19 pandemic and great lockdown. The continuing "lowtouch" production and consumption can further lead to inflation. Some papers focused on uncertainty and spending, and some others on the most affected sectors. Nevertheless, there are few papers in the literature addressing the connectedness between the COVID-19 pandemic and inflation rates.

Eichenbaum et al. (6) applied the canonical epidemiology model to analyze the effects of the pandemic on economic decisions in the US. The researchers found that the pandemic cut back the consumption which exacerbated the severity of the recession due to the COVID-19.

Altig et al. (1) compared the economic uncertainty indicators such as stock market volatility, business growth uncertainty, and uncertainties on the GDP growth for the US and UK, before and after the COVID-19 pandemic period. The researchers found that great uncertainty jumps in reaction to the pandemic and its economic outcomes. They calculated a $35 \%$ increase in the US economic uncertainty to a 20-fold rise in forecasting disagreement about UK economic growth. They also concluded that volatility started to increase towards the end of February and reached to peak in mid-March. It fell down towards the end of March since stock price started to recover. The authors also indicated that there was a sharp decline in industrial production of $12-19 \%$.

Andersen et al. (7) estimated the change in consumer spending during the COVID-19 pandemic in the Danish economy. The researchers calculated that aggregate spending was $27 \%$ below the counterfactual level without the pandemic. The spending fall was on the goods and services which are directly restricted during the lockdown. The spending drop was the highest among the people who lost their jobs, and the ones who lost their wealth during the pandemic.

Baker et al. (8) estimated the consumption response to the pandemic. They concluded that while household spending increased sharply in retail, credit card spending, and food in the early days of the pandemic, the spending showed sharp declines in restaurant and retail in the preceding months.

Dunn et al. (9) analyzed the effects of the COVID-19 pandemic on consumer spending. The researchers concluded that the greatest impact was on accommodation and restaurants with $80 \%$ and $70 \%$ respectively by the second week of March. On the contrary, there was a $100 \%$ increase in food and beverage sales. They concluded that there was an aggregate decline in spending of $13.7 \%$. They estimated the pandemic effect as $27.8 \%$ due to the measures. Coibion et al. (10) explored the spending patterns of households as well as their spending and macroeconomic expectations using the survey with more than 10.000 respondents. Half of the respondents reported income and wealth losses due to the pandemic. The respondent also expressed that they expected lower future inflation, higher uncertainty, and foreign stocks into liquid forms of savings. Sharif et al. (11) examined the relationship between the COVID-19 pandemic, oil price volatility shock, the stock market, geopolitical risk, and economic uncertainty in the US using Granger causality tests. They found that the effects of the COVID-19 on the geopolitical risk are much higher than on the US economic uncertainty. The pandemic risk was perceived differently for the short and long run. In a similar study, Pellegrino et al. (12) investigated the benefit of reducing policy uncertainty on GDP using a nonlinear VAR estimation for the Euro Area. The authors showed that the impact of the pandemic on the economy of uncertainty shocks is much higher during periods of a negative outlook for the future. They estimated the impact of COVID-19 induced uncertainty on industrial production as a peak value at a yearover-year growth loss of $-15.4 \%$ in September 2020, and a fall in CPI inflation between $1 \%-1.5 \%$.

Cavallo A. (13) investigated the changes in consumer expenditure patterns that caused the impact on the CPI. The author found that the inflation caused by the COVID19 was higher than the official CPI in the US for both headlines and core indices. There were similar findings with COVID-19 baskets for 10 out of 16 countries. The author also concluded that while social distancing precautions and behaviors cause more spending on food and other categories with rising inflation, they cause losses on transportation and related categories which experience significant deflation.

In her speech, Tenreyro S. (14) expressed that during the COVID-19 period in the UK, there were large, temporary changes in relative prices and consumption expenditures which caused inflation data difficult to interpret. She explained that although price inflation was under control, there was labor cost growth during the pandemic which is related to structural changes in the economy.

Apergis et al. (3) investigated the role of COVID-19 on inflation expectations and their volatility on the US economy. By using swap rates, the authors concluded that inflation expectations and their volatility are increased by the COVID-19 pandemic.

Jaravel et al. (15) analyzed the inflation dynamics during the pandemic period in the UK. The researchers calculated the inflation rate as $2.4 \%$ in the first month of the lockdown which is 10 times more than the previous months. They explained this loss with fewer promotions and decreasing the purchasing power of consumers. They also concluded that while $96 \%$ of households experienced inflation, half of the households experienced deflation in the preceding years. They also indicated that there may be a risk of stagflation in the UK economy.

Seiler P. (16) investigated the connectedness between the COVID-19 and inflation for Switzerland. By using debit card transactions, the author tried to analyze the changes 
in consumer spending and the Swiss consumer price index. He found that inflation was higher during the lockdown than suggested by CPI inflation.

Similarly, Lane T. (17) explained that during the quarantine process, inflation rates declined sharply particularly because of declines in prices of gasoline, travel services, and changes in spending in Canada. CPI-based on the cost of a fixed basket of goods has changed during the shutdown period. The fall in inflation experienced by consumers may be less than indicated by the official CPI measure. The author expressed the importance of the monetary policy to be forward-looking than usual.

Blundell et al. (18) examined the reflections of COVID-19 on the CPI. The spread of COVID-19 affected highdemand products such as medicine, nappies, rice, and pet food by a $1.1 \%$ rise. The findings indicated the increase in not only profit margin but also the cost of production due to the disruption of supply chains and production during the pandemic.

Bresser-Pereira L. (19) explained the government protections during the COVID-19 pandemic. Governments limited the expenditures not to increase public debt. The author also pointed out the contribution of central banks by buying securities from the Treasury to finance exceptional spending. The author also explained that while this policy does not contradict the inflation constraints, it may have conflicts with the fiscal constraints. However, it does not increase public debt. The researcher also explained that monetary financing of COVID-19 will not lead to excess demand that may increase imports, and current account deficit that may appreciate the national currency, accelerate inflation and lead to the currency crisis.

Ebrahimy et al. (20) examined the potential drivers and dynamics of inflation during the COVID-19 pandemic. For the early period of the pandemic, the researchers found evidence of inflation in food prices. However, there was no evidence of inflation in broader indexes.

Armantier et al. (21) explored consumer inflation expectation during the COVID-19 pandemic in the US. The researchers could not find a consistent upward or downward trend at the time they finalized the research. However, they pointed out that the data indicated unprecedented increases in individual inflation uncertainty.

\section{MATERIAL AND METHODS}

The present study deals with the main determinants of inflation during the first 7 months of 2020, when the COVID-19 crisis was in full swing, in the 28 European Union member and candidate states. In this way, the movement of inflation rates will be analyzed during the pandemic period. In the study, data on the European countries (Belgium, Bulgaria, Croatia, Czech Republic, Denmark, Estonia, Finland, France, Germany, Greece, Hungary, Ireland, Italy, Latvia, Lithuania, Luxembourg, Macedonia, Malta, Netherlands, Poland, Portugal, Romania, Serbia, Slovakia, Slovenia, Spain, Sweden, and Turkey) are discussed for the period between January 2020 and July 2020. The estimation model is shown in Equation [1].

inf $=\beta_{0}+\beta_{1}$ money $+\beta_{2}$ pricre $+\beta_{3}$ exc $+\beta_{4}$ indust $+\varepsilon_{i t}$

where inf is the domestic inflation rates of the countries, money is the amount of domestic money supply of the countries, price is domestic credit volume for the private sector, exc is the dollar-denominated exchange rate, indust is industrial production index and $\varepsilon_{i t}$ is error terms. Inflation rates represent the exchange rate of a basket related to the consumer price index of countries. The money supply shows the sum of cash and other liquid assets in circulation in the economy. Loans to the private sector show the volume of loans to non-financial private companies by commercial banks and other financial institutions that collect deposits. In the equation, i denotes units $(1, \ldots, N)$ and $t$ denotes time $(1, \ldots, T)$. Data were collected from the statistical institutions and central banks of the respective countries.

The first reason for the selection of European countries in the study is that the spread of the pandemic to Europe following China, and the high number of cases in Europe. Considering the course of the pandemic, it is seen that European countries take the first place regarding the number of cases and deaths. Another important point is that we have a theoretical expectation that the spatial impact is high in the European Union countries.

Spatial econometrics is preferred when the effect is not only caused by the characteristics of the spatial unit itself but also by its neighbors. This method can be used in many areas. The important point here is how spatial relationships are incorporated into the model. Spatial relationships can be modeled over contiguity relations or distance if geographic data are available. In our study, the distance relationships for European countries are preferred for the creation of the weight matrix to measure spatial effects.

For the modeling of spatial relationships, the Spatial Autoregressive Model (SAR), Spatial Error Model (SEM), Spatial Durbin Model (SDM) and General Spatial Model (SAC) models are commonly preferred. There is dependence in the SAR model resulting from spatial interaction. The SAR model can be indicated as follows:

inf $=\alpha_{0}+\rho \operatorname{Winf}+\alpha_{1} X+\varepsilon_{i t}$

In Equation [2], inf is the dependent variable, $X$ is nxk-size independent variables matrix, $W$ is nxn size weight matrix. The matrix $W$ represents the distance function. $\varepsilon_{i t}$ denotes error terms, $\mathrm{i}$ denotes units $1, \ldots, \mathrm{N}$ and $\mathrm{t}$ denotes time $1, \ldots, \mathrm{T}$. The contiguity structure can be fully represented by a spatial weight matrix (W). Here $\mathrm{W}$ is a measure of the links between the positions of the spatial units $i$ and $j$. Thus, the magnitude of interaction (direct effects) or spreading effects (indirect effects) between the neighbors can also be measured with the spatial dependence parameter.

Spatial effects in the SEM model arise from error terms. The spatial effects here are seen in the error term. The SEM model is included in Equation [3].

inf $=\alpha_{0}+\rho \operatorname{Winf}+\alpha_{1} X+\varepsilon_{i t}$

In Equation [3], $\rho=0$. Since the spatial effects here are included in the error term, $\varepsilon_{i t}=\lambda W \varepsilon+u, \quad u N\left(0, \sigma^{2} I_{n}\right)$, where $\lambda \neq 0$. The SAC model is made up of the combination of SAR and SEM models.

inf $=\alpha_{0}+\rho W_{1}$ inf $+\alpha_{1} X+\varepsilon_{i t}$

$\varepsilon_{i t}=\lambda W_{2} \varepsilon+u$

\section{Spatial Weight Matrix}

In our study, a weight matrix created with the inverse distance relationship is used to model spatial relationships. 
The inverse distance spatial weight matrix was created using the latitude and longitude of different spatial units (positions). The inverse distance weight matrix is calculated as follows:

$W_{i j}=\left\{\begin{array}{cc}\frac{1}{d_{i j}^{\alpha}} & \text { if } i \neq j \\ 0 & \text { if } i=j\end{array}\right.$

\section{RESULTS}

In our study, firstly cross-section dependencies and stationarities of the series are investigated. It is observed that all the series have cross-section dependencies. The cross-sectionally IPS (CIPS) test, one of the secondgeneration panel unit root tests, is preferred to investigate the stationarity status of the series. The results of unit root test indicate that all series are stationary at level. Considering the country group in our study, particularly the spreading effect of the pandemic, we have a preexpectation that there are strong spatial relations due to the close distance. Therefore, we use the Moran's I and Geary' $\mathrm{C}$ tests to investigate a priori the spatial effects for the inflation rates. According to the test results there is an effect in the context of the cross-section for the months included in the study. The results are shown in Table 1.

The results in Table 1 illustrates that there is a spatial effect for January, July, and June periods according to Moran's I test results, while there is a spatial effect for January, March, June, and July according to Geary 'C test results.
Considering the existence of spatial effects, we use spatial OLS methods in the study. Spatial OLS test results are shown in Table 2.

Table 1. Moran's I and Geary's C test results

\begin{tabular}{|c|c|c|c|c|c|}
\hline \multicolumn{6}{|c|}{ Moran's I } \\
\hline Months & I & $\mathbf{E}(\mathbf{I})$ & $\operatorname{sd}(\mathbf{I})$ & $\mathbf{z}$ & p-value* \\
\hline January & 0.047 & -0.037 & 0.031 & 2.686 & 0.004 \\
\hline February & -0.041 & -0.037 & 0.030 & -0.138 & 0.445 \\
\hline March & -0.011 & -0.037 & 0.030 & 0.854 & 0.197 \\
\hline April & -0.039 & -0.037 & 0.024 & -0.064 & 0.474 \\
\hline May & -0.044 & -0.037 & 0.030 & -0.219 & 0.413 \\
\hline June & -0.092 & -0.037 & 0.031 & -1.786 & 0.037 \\
\hline July & 0.010 & -0.037 & 0.030 & 1.569 & 0.058 \\
\hline \multicolumn{6}{|c|}{ Geary's C } \\
\hline Months & $\mathrm{C}$ & $E(c)$ & $\operatorname{sd}(c)$ & $\mathbf{z}$ & p-value* \\
\hline January & 0.912 & 1.000 & 0.035 & -2.509 & 0.006 \\
\hline February & 1.004 & 1.000 & 0.039 & 0.103 & 0.459 \\
\hline March & 0.934 & 1.000 & 0.042 & -1.580 & 0.057 \\
\hline April & 0.967 & 1.000 & 0.064 & -0.511 & 0.305 \\
\hline May & 0.960 & 1.000 & 0.041 & -0.991 & 0.161 \\
\hline June & 1.050 & 1.000 & 0.038 & 1.342 & 0.090 \\
\hline July & 0.928 & 1.000 & 0.041 & -1.751 & 0.040 \\
\hline
\end{tabular}

Table 2. Spatial OLS test results

\begin{tabular}{|c|c|c|c|c|c|c|c|}
\hline \multicolumn{8}{|c|}{ SAR } \\
\hline & Coef. & Std. Err. & $\mathbf{z}$ & Prob. & Tests & Stat. & Prob. \\
\hline lnmoney & 0.107 & 0.061 & 1.770 & 0.076 & GLOBAL Moran MI & 0.0529 & 0.0067 \\
\hline Inpricre & -0.100 & 0.070 & -1.410 & 0.157 & GLOBAL Geary GC & 0.9137 & 0.0006 \\
\hline $\operatorname{lnexc}$ & 0.068 & 0.021 & 3.240 & 0.001 & GLOBAL Getis-Ords GO & -0.053 & 0.0067 \\
\hline indust & 0.003 & 0.003 & 0.780 & 0.433 & Moran MI Error Test & 2.3251 & 0.0201 \\
\hline Cons & -0.049 & 0.187 & -0.260 & 0.793 & & & \\
\hline rho & 0.392 & 0.121 & 3.240 & 0.001 & & & \\
\hline Hausman Test & chi2 & 10.830 & Probability & 0.055 & & & \\
\hline \multicolumn{8}{|c|}{ SEM } \\
\hline & Coef. & Std. Err. & $\mathbf{z}$ & Prob. & Tests & Stat. & Prob. \\
\hline lnmoney & 2.369 & 2.319 & 1.020 & 0.307 & GLOBAL Moran MI & 0.0529 & 0.0067 \\
\hline lnpricre & -0.229 & 3.167 & -0.070 & 0.942 & GLOBAL Geary GC & 0.9137 & 0.0006 \\
\hline $\operatorname{lnexc}$ & -5.102 & 4.132 & -1.230 & 0.217 & GLOBAL Getis-Ords GO & -0.0529 & 0.0067 \\
\hline indust & -0.003 & 0.005 & -0.480 & 0.633 & Moran MI Error Test & 2.3251 & 0.0201 \\
\hline Cons & 0.531 & 0.1528 & 3.47 & 0.001 & & & \\
\hline lambda & 0.452 & 0.111 & 4.080 & 0.000 & & & \\
\hline Hausman Test & chi2 & 7.390 & Probability & 0.193 & & & \\
\hline \multicolumn{8}{|c|}{ SDM } \\
\hline & Coef. & Std. Err. & $\mathbf{z}$ & Prob. & Tests & Stat. & Prob. \\
\hline lnmoney & 0.093 & 0.059 & 1.580 & 0.114 & GLOBAL Moran MI & 0.0477 & 0.0137 \\
\hline lnpricre & -0.072 & 0.056 & -1.280 & 0.200 & GLOBAL Geary GC & 0.9188 & 0.0012 \\
\hline $\operatorname{lnexc}$ & 0.058 & 0.035 & 1.640 & 0.102 & GLOBAL Getis-Ords GO & -0.0477 & 0.0137 \\
\hline indust & 0.004 & 0.005 & 0.760 & 0.450 & Moran MI Error Test & 2.053 & 0.0401 \\
\hline Cons & -0.673 & 2.114 & -0.320 & 0.750 & & & \\
\hline rho & 0.392 & 0.130 & 3.020 & 0.003 & & & \\
\hline Hausman Test & chi2 & 45.830 & Probability & 0.000 & & & \\
\hline
\end{tabular}


Based on the data in Table 2, it is decided that the spatial effect exists according to the rho test results estimated for the SAR and SDM models for the random-effects model and according to the lambda test result for the SEM model. For these models, when the results of Global Moran MI, Global Geary GC, Global Getis-Ords GO, Moran MI Error Test are examined, the null hypothesis claiming that there is no spatial effect is rejected and it is decided that there is a spatial effect. An important point here is the efficiency of the estimator of the random-effects model. The Hausman test results indicated that the random effects estimator is effective for the SAR and SDM models, and the fixed effects estimator is effective for the SEM model. The results obtained with the fixed effects estimator for the SEM model showed that there is no spatial effect. On the other hand, the results of the SDM model showed that the coefficients of the variables are not statistically significant. Finally, it was decided that the random effects estimator for the SAR model was effective and spatial effects exist. Spatial impacts can be either direct or indirect. Therefore, it is important to separate the effects. Spatial effects related to the SAR model are included in Table 3 as indirect and direct effects.

Table 3. Total, direct and indirect effects for the SAR model

\begin{tabular}{ccccc}
\hline \multicolumn{5}{c}{ Total Effects } \\
\hline Inmoney & $\mathbf{0 . 1 0 7}$ & $\mathbf{0 . 0 6 1}$ & $\mathbf{1 . 7 7 0}$ & $\mathbf{0 . 0 7 6}$ \\
lnpricre & -0.100 & 0.070 & -1.410 & 0.157 \\
lnexc & $\mathbf{0 . 0 6 8}$ & $\mathbf{0 . 0 2 1}$ & $\mathbf{3 . 2 4 0}$ & $\mathbf{0 . 0 0 1}$ \\
indust & 0.003 & 0.003 & 0.780 & 0.433 \\
Cons & -0.049 & 0.187 & -0.260 & 0.793 \\
\hline \multicolumn{5}{c}{ Direct Effects } \\
\hline lnmoney & $\mathbf{0 . 1 1 1}$ & $\mathbf{0 . 0 6 3}$ & $\mathbf{1 . 7 7 0}$ & $\mathbf{0 . 0 7 7}$ \\
lnpricre & -0.104 & 0.073 & -1.430 & 0.151 \\
Inexc & $\mathbf{0 . 0 7 2}$ & $\mathbf{0 . 0 2 1}$ & $\mathbf{3 . 4 6 0}$ & $\mathbf{0 . 0 0 1}$ \\
indust & 0.002 & 0.003 & 0.750 & 0.454 \\
\hline \multicolumn{5}{c}{ Indirect Effects } \\
\hline lnmoney & 0.073 & 0.059 & 1.240 & 0.214 \\
lnpricre & -0.065 & 0.059 & -1.100 & 0.271 \\
lnexc & 0.050 & 0.033 & 1.510 & 0.130 \\
indust & 0.002 & 0.003 & 0.550 & 0.582 \\
\hline
\end{tabular}

Table 3 illustrates that the coefficients related to indirect effects are not statistically significant and there are direct effects for our estimated model. In this context, it is observed that the increases in money supply and exchange rate for the period considered stir up the increase in inflation. However, it has been observed that the credit increase for the private sector did not increase inflation. As a possible reason for this, it is thought that the loans extended to the private sector are used to get out of the difficult situation of the sector such as debt payment. Thus, the increase in credit supply does not have a positive effect on prices. On the other hand, the slowdown in industrial production caused the production-inflation relationship to break. Therefore, the effects of industrial production on inflation disappear during the pandemic period.

\section{DISCUSSION and CONCLUSION}

In our study, the determinants of inflation for European countries (Belgium, Bulgaria, Croatia, Czech Republic, Denmark, Estonia, Finland, France, Germany, Greece, Hungary, Ireland, Italy, Latvia, Lithuania, Luxembourg, Macedonia, Malta, Netherlands, Poland, Portugal, Romania, Serbia, Slovakia, Slovenia, Spain, Sweden, and Turkey) were investigated with spatial panel data methods taking into consideration the proximity of the countries for the period between January 2020 - July 2020. According to the empirical results, it was found that the exchange rate and money supply ratios were reasons of the increase in inflation. Behind the increase in inflation, there is increasing pressure on the inflation rates due to the domestic money supply and exchange rate variables as well as the neighborhood relations (positive spatial effects).

It is an important finding for the policy-making processes that macroeconomic problems in each sample country are also affected by developments in neighboring countries as well as internal dynamics. Continuous development of economic, social, and political cooperation between neighboring countries at the regional and global levels is essential. It is reasonable for every country to develop selfsufficient strategies in the fields of agriculture, food, technology, and pharmaceutical industries in case of global disasters. However, it is not possible to eliminate the effects of external shocks. While critical sectors that are vital in times of disaster are supported at the national level, initiatives at regional and global levels should not be ignored. Regional cooperation should not be limited to the development of sectors that stand out during the pandemic period. The framework of economic cooperation initiatives should be kept as broad as possible. It should not be forgotten that it is not possible for any country to solve its problems by completely isolating itself from the rest of the world.

Ethics Committee Approval: Since our study was not an experimental study including human or animal subject, Ethics Committee approval was not required.

Conflict of Interest: None declared by the authors.

Financial Disclosure: None declared by the authors.

Acknowledgements: None declared by the authors.

\section{REFERENCES}

1. Altig D, Baker S, Barrero JM, Bloom N, Bunn P, Chen $\mathrm{S}$, et al. Economic uncertainty before and during the COVID-19 pandemic. Journal of Public Economics. 2020;191:104274.

2. nytimes.com [Internet]. The New York Times. Fed chair warns this is a 'downturn without modern precedent'. [Cited: 2020 September 12]. Available from: https://www.nytimes.com/2020/05/21/business/ economy/fed-chair-warns-this-is-a-downturn-withoutmodern-precedent.html

3. Apergis E, Apergis N. Inflation expectations, volatility and COVID-19: Evidence from the US inflation swap rates. Applied Economics Letters. 2020; [Epub ahead of print]. doi: 10.1080/13504851.2020.1813245. 
4. Ilzetzki E, Reinhart CM, Rogoff KS. Will secular decline in exchange rate and inflation volatility survive COVID-19? Brooking Papers on Economic Activity. BPEA Conference Drafts. [Cited: 2020 September 12]. Available from: https://www.brookings.edu/wp-content /uploads/2020/09/Ilzetzki-et-al-conference-draft.pdf.

5. imf.org [Internet]. International Monetary Fund. The great lockdown: Worst economic downturn since the great depression. [Cited: 2020 September 12]. Available from: https://blogs.imf.org/2020/04/14/thegreat-lockdown-worst-economic-downturn-since-thegreat-depression/.

6. Eichenbaum MS, Rebelo S, Trabandt M. The macroeconomics of epidemics. NBER Working Papers. 2020;26882. doi: 10.3386/w26882.

7. Andersen AL, Hansen ET, Johannesen N, Sheridan, A. Responses to the COVID-19 crises: Evidence from bank account transaction data. CEBI Working Paper Series. 2020;18/20. Available from: https://www.econ.ku.dk/cebi/publikationer/workingpapers/CEBI_WP_18-20_rev.pdf.

8. Baker SR, Farrokhnia RA, Meyer S, Pagel M, Yannelis C. How does household spending respond to an epidemic? Consumption during the 2020 COVID-19 Pandemic. NBER Working Papers. 2020;26949. doi: $10.3386 / \mathrm{w} 26949$.

9. Dunn AC, Hood KK, Driessen A. Measuring the effects of the COVID-19 pandemic on consumer spending using card transaction data. BEA Working Paper Series. 2020;5. Available from: https://www. bea.gov/system/files/papers/BEA-WP2020-5_0.pdf.

10. Coibion O, Gorodnichenko Y, Weber M. The cost of the COVID-19 crisis: lockdowns, macroeconomic expectations, and consumer spending. NBER Working Papers. 2020;27141. doi: 10.3386/w27141.

11. Sharif A, Aloui A, Yarovaya L. COVID-19 pandemic, oil prices, stock market, geopolitical risk, and policy uncertainty nexus in the US economy: Fresh evidence from the wavelet-based approach. International Review of Financial Analysis. 2020;70:101496.

12. Pellegrino G, Ravenna F, Züllig G. The cost of coronavirus uncertainty: The high returns to clear policy plans. The Australian Economic Review. 2020;53(3):397-401.

13. Cavallo A. Inflation with COVID-19 consumption baskets. NBER Working Paper Series. 2020;27352. doi: $10.3386 /$ w2 27352 .

14. bankofengland.co.uk [Internet]. Bank of England. Tenreyro S. Monetary policy during pandemics: inflation before, during, and after COVID-19. [Cited: 2020 September 12]. Available from: https://www. bankofengland.co.uk/speech/2020/silvana-tenreyrospeech-monetary-policy-during-pandemics.

15. Jaravel $\mathrm{X}$, O'Connell $\mathrm{M}$. Inflation spike and falling product variety during the Great Lockdown. Institute for Fiscal Studies (IFS) Working Papers. 2020;W20/17. doi: 10.1920/wp.ifs.2020.1720.

16. Seiler P. Weighting bias and inflation in the time of COVID-19: Evidence from Swiss transaction data. Swiss Journal of Economics and Statistics. 2020;156:13.

17. bankofcanada.ca [Internet]. Bank of Canada. Lane T. Policies for the Great Global Shutdown and beyond. [Cited: 2020 September 12]. Available from: https://www.bankofcanada.ca/2020/05/policies-greatglobal-shutdown-and-beyond/.

18. Blundell R, Griffith R, Levell P, O’Connell M. Could COVID-19 infect the consumer price index? Fiscal Studies. 2020;41(2):357-61.

19. Bresser-Pereira LC. Financing COVID-19, inflation and fiscal constraint. Forum for Social Economics. 2020;49(3):241-56.

20. Ebrahimy E, Igan D, Peria M. The impact of Covid-19 on inflation: Potential drivers and dynamics. IMF Special Notes Series on Covid-19. September 10, 2020:1-14.

21. Armantire O, Kosar G, Pomerantz R, Skandalis D, Smith $\mathrm{K}$, Topa $\mathrm{G}$, et al. Inflation expectations in times of COVID-19. Federal Reserve Bank of New York, Liberty Street Economics. [Cited: 2020 September 12]. Available from: https://libertystreeteconomics.newyorkfed.org/20 20/05/inflation-expectations-in-times-of-covid-19.html. 